\title{
Wetlands need people: a framework for understanding and promoting Australian indigenous wetland management
}

\author{
$\underline{\text { Michelle L. Pyke }}^{1}, \underline{\text { Sandy Toussaint }}^{2}, \underline{\text { Paul G. Close }}^{3}, \underline{\text { Rebecca J. Dobbs }}^{3}$, Irene Davey $^{4}, \underline{\text { Kevin J. George }}^{5}, \underline{\text { Daniel Oades }}^{5}, \underline{\text { Deborah }}$ \\ $\underline{\text { Sibosado }}^{6}, \underline{\text { Phillip McCarthy }}^{5}$, Cecelia Tigan $^{6}, \underline{\text { Bernadette Angus (Jnr) }}^{6}, \underline{\text { Elaine Riley }}^{6}, \underline{\text { Devena Cox }}^{7}, \underline{\text { Zynal Cox }}^{7}, \underline{\text { Brendan Smith }}^{7}$, \\ Preston Cox $^{7}$, Albert Wiggan ${ }^{7}$ and Julian Clifton ${ }^{1}$
}

\begin{abstract}
Indigenous knowledge systems (IKSs) can, and do, contribute to natural resource management (NRM) in Australia and elsewhere. However, cross-cultural NRM and scientific research usually emphasizes particular components of IKSs, rather than engaging with the value of an integrated complex IKS. Focusing on two case studies of Aboriginal groups in the Kimberley region of northwestern Australia, we present a conceptual framework that represents how IKSs can manifest as a system of wetland management. The framework depicts how beliefs, knowledge, and practices are inter-related, forming a meaningful and organized approach in which indigenous Bardi Jawi and Nyul Nyul people historically managed, and aspire to continue managing nearby Customary Law-inherited wetlands. The framework presents a meso-scale representation of IKSs that highlights four management principles: custodianship, respectful use, active maintenance, and learning. We describe how affinities for these principles, vis-à-vis other indigenous groups, can also be discerned. Providing a visual framework tool has the potential to assist the application of IKSs to wetland management, and take account of the view that "wetlands need people," by emphasizing the active, integrated, and reciprocal nature of these knowledge systems in place (associated with traditional lands). That indigenous people value, as well as shape, wetlands, is also considered. By interpreting the framework to support indigenous wetland management (and services to ecosystems) within active cross-cultural work, IKSs promise benefits for people and ecosystems.
\end{abstract}

Key Words: collaboration; cross-cultural ecology; ecosystem stewardship; indigenous ecological knowledge; Kimberley; natural resource management; services to ecosystems; wetland management

\section{INTRODUCTION}

Indigenous knowledge systems (IKSs) can, and do, contribute to natural resource management (NRM; Berkes et al. 2000, Ens et al. 2015) if there are opportunities for indigenous people and scientists or NRM practitioners to undertake effective collaboration. Collaborative NRM often relies on integrating indigenous knowledge (IK) with conventional NRM practice and academic-inspired scientific knowledge (SK; Bohensky and Maru 2011); however, within these cross-cultural collaborations, the complexity of IK is not always fully realized (Muller 2012). Projects within the natural sciences, for instance, involve components of IKSs that might complement conventional perspectives but sometimes preclude other dimensions of IK from consideration (Barbour and Schlesinger 2012). Notably, conceptual frameworks methodologically driven within the complexity of IKSs, while remaining relevant to NRM, are canvassed by Holmes and Jampijinpa (2013) and Walsh et al. (2013). Generated through extensive fieldwork with two Australian Aboriginal, or indigenous, groups, our discussion offers a conceptual framework that highlights (particularly to wetland ecologists and managers) how multiple and interacting dimensions of IKSs relate to enduring wetland management.

The framework adopts a meso-scale perspective, identifying a link between complex and nonbinary or oppositional macro- and microconceptual scales, similar to those outlined by Walsh et al.
(2013) and Holmes and Jampijinpa (2013). Macro-scale analyses provide all-encompassing definitions, conceptualizations, and applications of IKSs (e.g., Gadgil et al. 1993, Berkes et al. 2000). For example, Berkes and colleagues liken IK-based practices and associated institutions to adaptive management and systems of logic that can inform or improve conventional NRM (Berkes et al. 2000, Berkes and Berkes 2009). Microscale analyses tend to focus on specific species or places, an approach often adopted in natural science research related to ecosystem management, as well as the social sciences, such as in ethnographic research. Certain microscale analyses within wetland management research have investigated components of IK pertaining to a particular species or wetland function (Calheiros et al. 2001, Silvano et al. 2008, Hallwass et al. 2013, Liedloff et al. 2013, Jackson et al. 2014), indicators of wetland condition (Ens et al. 2010, Gratani et al. 2016), and the application of specific management techniques (Kusabs and Quinn 2009, Gratani et al. 2011). In contrast, mesoscale analyses emphasize not only components of IK, but also how these are generated from, and related to, beliefs, practices, and cultural or social institutions. Such integrated analyses engender new ideas for water management that involve local human action and better incorporate the cultural and social dimensions of water/human engagement, such that macro- and microconceptual scales are more clearly linked within a place (see Singh 2006, Rea and the Anmatyerr Water Project Team 2008, Noble et al. 2016).

${ }^{1}$ UWA School of Agriculture and Environment, The University of Western Australia, ${ }^{2}$ School of Social Sciences and the Centre of Excellence in Natural Resource Management, The University of Western Australia, ${ }^{3}$ Centre of Excellence in Natural Resource Management, The University of Western Australia, ${ }^{4}$ Bardi Jawi Traditional Owner, ${ }^{5}$ Bardi Jawi Rangers, Kimberley Land Council, ${ }^{6}$ Bardi Jawi Oorany Rangers, Kimberley Land Council, ${ }^{7}$ Nyul Nyul Rangers, Kimberley Land Council 
Table 1. Some Bardi Jawi and Nyul Nyul terms for freshwater and terms used in this paper (for Bardi Jawi words see Aklif 1999).

\begin{tabular}{|c|c|c|}
\hline Language group & Term & Definition \\
\hline \multirow[t]{6}{*}{ Bardi Jawi } & biidin & $\begin{array}{l}\text { A source of freshwater in the ground accessed by digging a hole in beach sand, often } \\
\text { above the high tide mark within dune swales. Sometimes referred to as wells or waterholes. }\end{array}$ \\
\hline & booroo & Home territory, country \\
\hline & oola & Freshwater \\
\hline & oomban & $\begin{array}{l}\text { A source of freshwater accessed by digging a hole in beach sand below the high tide mark. } \\
\text { Sometimes referred to as soaks. }\end{array}$ \\
\hline & oongoor & Freshwater (rain) that collects on rocks \\
\hline & raya & Spirit child \\
\hline Nyul Nyul & nigilbuninj & Freshwater eel (Anguilla bicolor) \\
\hline
\end{tabular}

Holmes, Jampijinpa, and others (e.g., Dwyer 2012, Comberti et al. 2015) emphasize that IKSs are characterized by an ethic of reciprocity in which the actions of humans and nature are "... understood to support the healthy functioning of the other" (Holmes and Jampijinpa 2013). By incorporating beliefs, knowledge, practices, and institutions, and their interactions, a meso-scale analysis of an IKS can express this reciprocal relationship (Holmes and Jampijinpa 2013, Walsh et al. 2013). Associated with this reciprocity, IKSs also relate to developing NRM concepts such as "services to ecosystems," in which indigenous people's activities are recognized for their contributions to maintaining and enhancing ecosystems (Comberti et al. 2015). Given that in Australia and elsewhere, indigenous people's practices have maintained and enhanced wetlands (Humphries 2007, McGregor et al. 2010, Verzijl and Quispe 2013, Barber and Jackson 2014), we emphasize the reciprocal relationship that exists between Aboriginal people and these ecosystems.

A meso-scale conceptual framework has the potential to bridge the natural and social science disciplines, including via use of ethnographic methods (Strang 2009a). For example, rich ethnographic accounts of Australian Aboriginal freshwater perspectives offer distinctive and potentially productive ways to conceptualize the management of wetlands and associated species or threats (e.g., Young 2006, Toussaint 2014). Although ethnographic data is becoming increasingly familiar to practitioners of applied scientific methods, this is not always or consistently the case according to Strang (2009a). A challenge therefore exists: to depict qualitative information on IKSs in a way that is complex yet comprehensible to all researchers (Strang 2009a), including NRM practitioners and scientists (also see Gratani et al. 2011). Conceptual frameworks, such as those generated by Walsh et al. (2013) and Holmes and Jampijinpa (2013), distill complex information into a simple visual format to aid scientists and NRM practitioners to better comprehend IKSs and how they relate to an environmental management issue. Extending from Walsh et al. (2013) and Holmes and Jampijinpa (2013) who focus on plants and threatened species management, respectively, our emphasis is wetland management with a view to contributing to those working in wetland-related cross-cultural collaborations in northern Australia and parallel settings (see Crook et al. 2016).

Wetlands are of high conservation value across northern Australia, although threatened by water resource use and other pressures (Pusey 2011, Close et al. 2012) and, as we make plain, central to the beliefs, practices, and knowledge of Aboriginal groups (Toussaint et al. 2001, 2005, Jackson and O'Leary 2006, Langton 2006, Yu 2006, Strang 2009b). Aboriginal people believe that the earth's landscapes and life forms were (and are) generated by ancestral figures (creator spirits) during the inception and continuity of the Dreaming (as indigenous religion and law is often described in English, although with language-specific descriptors belonging to different groups). These creator spirits came to rest within landforms, many within wetlands (Toussaint et al. 2001, 2005). Affiliated with these and other metaphysical forces, wetlands are often considered significant cultural sites, and provide places of ceremonial, economic, historical, and recreational importance. Many Aboriginal groups express an obligation to care for wetlands, which can comprise symbolic and practical activities.

The Bardi Jawi and Nyul Nyul peoples are two Aboriginal groups who, like others across northern Australia (Jackson et al. 2005), seek to protect wetlands on their traditional lands, or "country." With their affiliations with tracts of country lying adjacent on the Dampier Peninsula, west Kimberley region of northwestern Australia (Fig. 1), the Bardi Jawi and Nyul Nyul peoples host indigenous ranger teams that conduct cultural and natural resource management, supported by the peak regional Kimberley indigenous body, the Kimberley Land Council. Both ranger teams aim to protect, maintain, or enhance the condition of wetlands on their respective countries using both their own IKSs and SK (see Oades and Meister 2013, NAILSMA 2014, Dobbs et al. 2016). Bardi Jawi people refer to wetlands as "...traditional Oola (water) places"(Oades and Meister 2013:37), a nomenclature that has been adopted in this article as "water places" and used interchangeably with wetlands. Both groups recognize water places that are associated with surface and ground water (for example see Pettit et al. 2016), many of which are individually named (see Aklif 1999, Dobbs et al. 2016), with local terms for freshwater species and places also still used (Table 1).

As with indigenous groups across Australia and elsewhere, the Bardi Jawi and Nyul Nyul societies have undergone significant transformation since colonization (see Choo 1997, McGregor 2003, Glaskin 2007). Despite these pressures and changes, many Bardi Jawi and Nyul Nyul people continue to live on their traditional lands and engage in cultural and customary activities and institutions. Bardi Jawi has been granted native title through the Federal Government 1994 Native Title Act, and acknowledgement as an Indigenous Protected Area (Oades and Meister 2013); the Nyul Nyul people have also been recognized as native title holders. On the Dampier Peninsula the four major 
communities of Ardiyooloon, Lombadina, Djarindjin, and Beagle Bay (Fig. 1), collectively host between 650-950 mostly Bardi Jawi and Nyul Nyul people (Western Australian Planning Commission 2015). Around 450-650 people live in smaller family settlements on "blocks" (outstations or homelands) along the coast of the peninsula (Western Australian Planning Commission 2015). Both groups maintain custodial or traditional tenure systems in which, within the larger language group, family units are affiliated with smaller, well-defined territories (called booroos in Bardi; see Elkin 1933, Smith 1984, Bowern 2009), some of which now comprise outstations.

Fig. 1. Location of the Bardi Jawi and Nyul Nyul Ranger management areas on the Dampier Peninsula north of Broome, Western Australia.

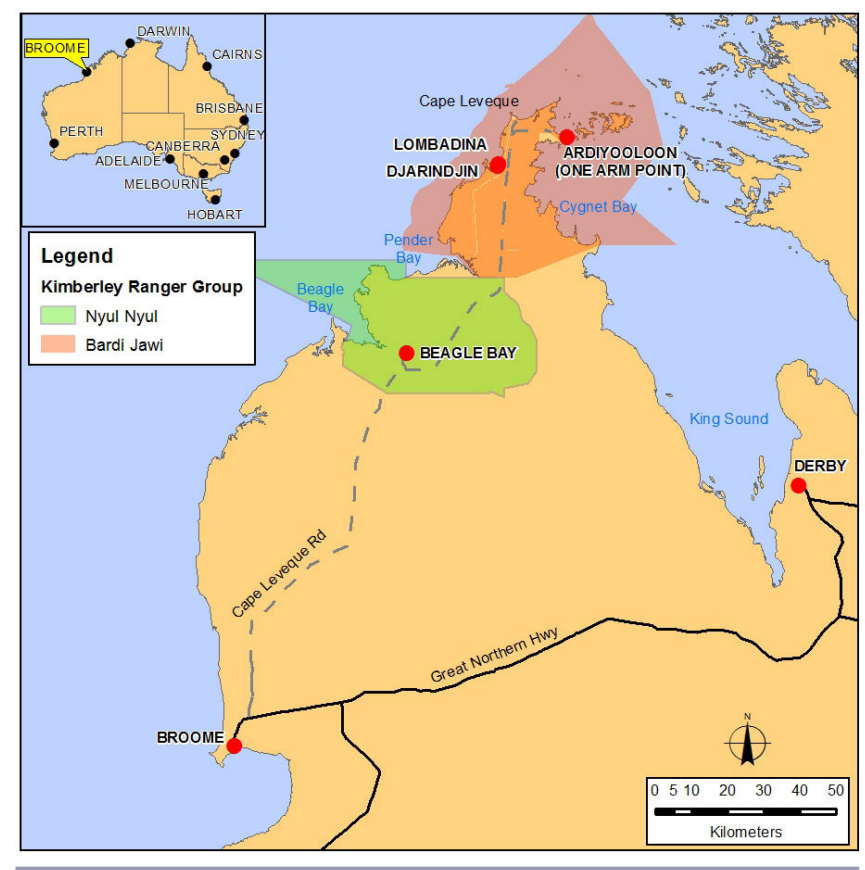

Through two case studies with the Bardi Jawi and Nyul Nyul peoples, a conceptual framework that depicts how each groups' IKS relates to wetland management (Fig. 2) has arisen. After a brief discussion of methods, the conceptual framework is explained, comprising three central beliefs, four principles, and multiple related elements. The beliefs (inner blue circle, Fig. 2) describe the nature of human-wetland relationships as perceived by Bardi Jawi and Nyul Nyul participants. The four principles (orange circles) include custodianship, respectful use, active maintenance and learning. We discuss how, through these beliefs, principles, and their expressions (captured as elements, the white circles), Bardi Jawi and Nyul Nyul people engage in a system of wetland management that has purpose and structure, with similarities to systems engaged in by other indigenous groups. We lastly discuss how, through the lens of wetland/human agency, interactions, and cultural management, these groups offer services to ecosystems that potentially generate positive outcomes for both people and wetlands.

\section{METHODS}

Addressing the concerns of indigenous and nonindigenous scholars (Davis and Ruddle 2010, Barbour and Schlesinger 2012), and national and regional ethical policy (AIATSIS 2011, KLC 2011), the research process relied on scientific rigour alongside a benefit for participants, and a contribution to knowledge. Research collaboration between the lead author (MP) and indigenous ranger teams facilitated these objectives, with the Bardi Jawi Rangers (men), Bardi Jawi Oorany (BJO) Rangers (women), and the Nyul Nyul Rangers (men and women) each involved. Ethics approvals were gained from the University of Western Australia (RA/4/1/6504), the Kimberley Land Council, and local governing bodies from the Bardi Jawi and Nyul Nyul communities. Three main stages occurred: (1) semistructured interviews with Aboriginal participants about a wetland (or wetlands) of their choice, (2) a participatory review and analysis of interview results, and (3) formal and informal discussions with rangers and representative elders to review and develop research findings. MP lived in a Bardi Jawi community for one year prior and three years during the research, a unique vantage point that fostered local interactions and facilitated regular dialogue with each ranger team and community members more broadly.

Ranger team roles varied in stage one. The Nyul Nyul Rangers preferred to assist MP as the interviewer, whereas the BJO Rangers preferred to conduct interviews with MP attending and assisting. All interviews used a standard set of questions (Appendix 1). The BJO Rangers also video-recorded interviews for their own records and assisted MP to review preliminary interview progress, with the rangers suggesting an additional question to ensure no cultural information was unintentionally missed (Q. 9 in Appendix 1). Ranger assistance with nearly all interviews helped to prevent misinterpretation of interview questions as the rangers "code-switched," that is, offered Aboriginal language or locally familiar English terms to explain concepts. Where possible interviews took place at wetlands, which facilitated direct engagement with Aboriginal knowledge systems for both participants and researchers (as in Woodward and Marrfurra McTaggart 2015). Otherwise, for example, where a participant's mobility was limited, interviews were held at a place suggested by the participant, generally either at their home or at the local ranger base. Interviews took place between March 2014 and November 2015, involving 21 field days and a two-night camp for each group, and visits to at least 20 Bardi Jawi and 13 Nyul Nyul wetlands. Observation of participants and ranger coresearchers during fieldwork planning and execution formed an additional information source.

Deciding which indigenous community members to interview (such as young or elderly people), was an important consideration (as per Davis and Wagner 2003, Huntington 2005). The research sought to understand, where possible, how human-wetland relationships were historically (and continue to be) culturally expressed, and whether Bardi Jawi and Nyul Nyul people wish to revitalize any such relationships that have changed. With this focus on cultural, including historical, knowledge and memories, the participation of individuals considered cultural knowledge authorities, generally elderly men and women ( $>65$ years), was encouraged. We also interviewed younger people (25-65), with many contributors (both young and old) being traditional owners, those individuals and family groups with recognized cultural 
Fig. 2. Conceptual framework depicting the Bardi Jawi and Nyul Nyul wetland management system, including beliefs (inner blue circle), principles (orange circles), and related elements (small circles).

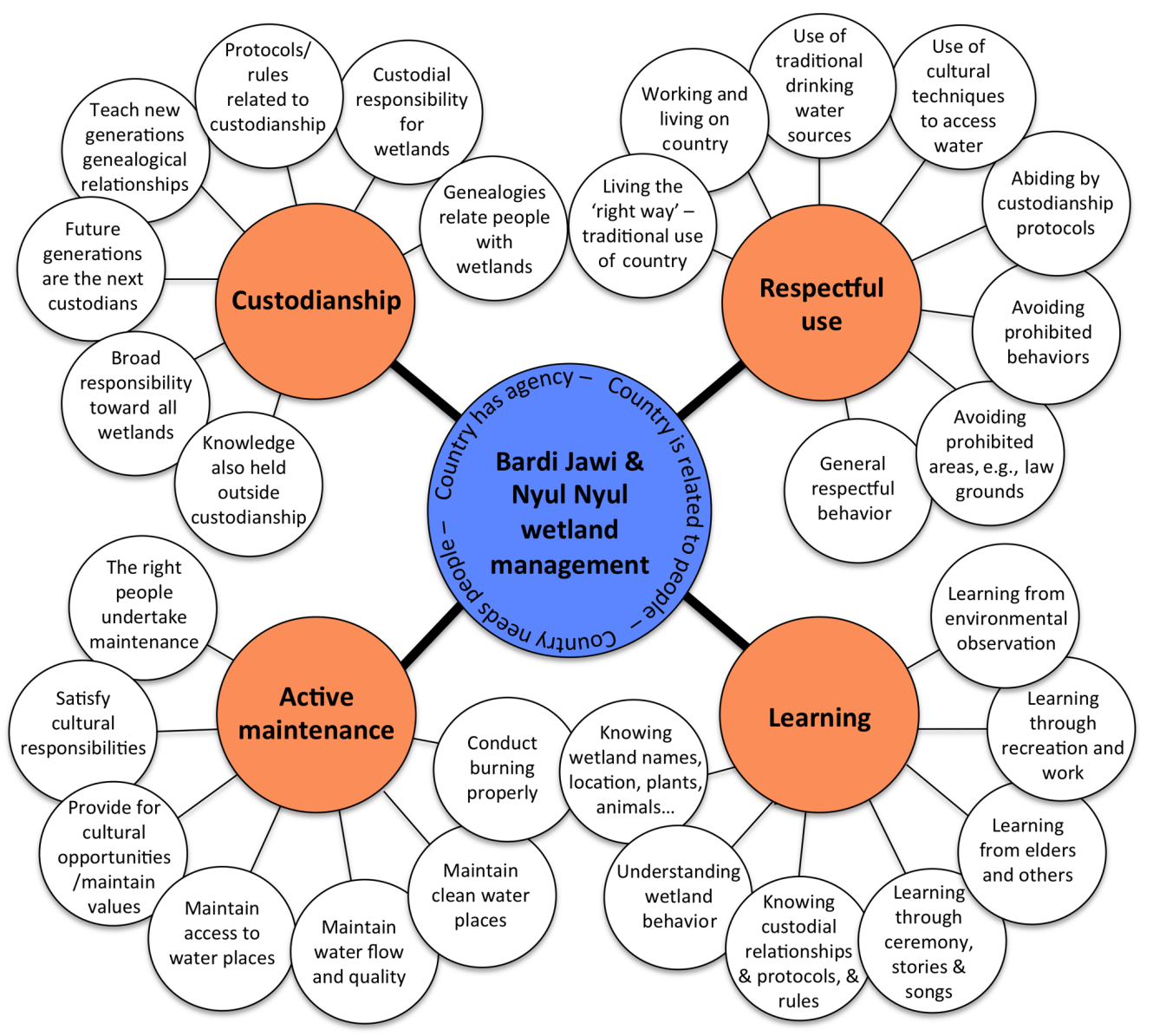

affiliations to, or custodianship of, particular wetlands (see KLC 2011). For Bardi Jawi, their Prescribed Body Corporate (representative native title governing body) and the ranger team's cultural advisor referred participants; the Nyul Nyul Rangers offered referrals as a team. Both men and women were interviewed, involving a particularly high number (19) of senior (65-75) and elderly (75+) Bardi Jawi people (Table 2). Interviews were stopped after reasonable efforts had been made to recruit all referred participants and when no new themes were arising.

The second stage involved a participatory review of themes arising from interviews. The BJO Rangers, Bardi Jawi IPA Coordinator, and MP cofacilitated a one-day interactive workshop involving 12 Bardi Jawi elders, representing a high turnout of respected knowledge holders. For the Nyul Nyul group, MP presented research findings during a meeting of the ranger's advisory committee, with six elders and 11 rangers present. Key themes presented at both meetings included the following: types of knowledge about wetlands; ways in which people and wetlands are connected; ways of looking after wetlands; perceptions of wetland condition (health); causes of wetland change or decline; spiritual associations; and ways of teaching and sharing knowledge. Participants were asked to offer any concerns, identify any errors or emissions, or contribute additional thoughts.
Interview transcripts, detailed notes from meetings, and observational field notes made up three data sources for content analysis. Also, all Nyul Nyul and Bardi Jawi words were compiled in a glossary and defined based on available literature, particularly drawing upon Aklif (1999) for Bardi Jawi. Content analysis is a method for the systematic interpretation of patterns within or characteristics of a text (Neuendorf 2002), used in our research to investigate how indigenous knowledge relates to wetland management. All data were entered into NVivo software (QSR 2016) and coded according to six main themes and related subthemes (Table 3). The coding frame (Table 3) emerged by working with Aboriginal coresearchers and participants, and their contributions, to see what was important within their cultural frame, while also being informed by literature on IKSs. Initially MP identified themes arising from the data and corroborated these against IKS literature to develop a broad coding frame (Table A2.1). The coding frame included factual knowledge, management systems and use, and beliefs/worldviews (about wetlands), reflecting three categories of IKSs recognized by some social researchers (see Leonard et al. 2013). The fourth code, "learning process," reflected indigenous ways of generating and sharing knowledge that are considered within IKS literature 
Table 2. Age and gender of participants interviewed (female: X-f, male: X-m).

\begin{tabular}{|c|c|c|c|c|c|}
\hline & \multicolumn{4}{|c|}{ Age group } & \multirow[b]{2}{*}{ Total } \\
\hline & $\begin{array}{l}25-45 \\
\text { young }\end{array}$ & $\begin{array}{c}45-65 \\
\text { middle-aged }\end{array}$ & $\begin{array}{l}65-75 \\
\text { senior }\end{array}$ & $\begin{array}{c}75+ \\
\text { elderly }\end{array}$ & \\
\hline Bardi Jawi & $3-f, 0-m(3)$ & $1-f, 3-m(4)$ & $5-f, 5-m(10)$ & 6-f, 3-m (9) & 26 \\
\hline Nyul Nyul & $1-f, 2-m(3)$ & 8-f, 1-m (9) & $2-\mathrm{f}, 2-\mathrm{m}(4)$ & $0-\mathrm{f}, 3-\mathrm{m}(3)$ & 19 \\
\hline
\end{tabular}

as underpinning IKS maintenance (e.g., Berkes et al. 2000). Over time analysis using the broad coding frame, including collaborative analyses, revealed frequently mentioned themes and subthemes that directly related to wetland ecosystem management, and that became the final coding frame used in this research (Table 3). After coding MP developed a draft conceptual framework to express the interconnection of themes, which encompassed beliefs, practices, knowledge, and institutions relating to Bardi Jawi- and Nyul Nyul-wetland interactions. Throughout data analysis, and emphasizing our collaborative research approach, Aboriginal participants and coresearchers contributed to developing coding frames, interpreting data, and reviewing and representing findings. Collaborative analyses included formal activities and meetings with ranger teams, the participatory reviews, and various informal opportunities.

The rangers' ongoing collaboration with MP living locally facilitated multiple opportunities for interaction and reflection on both general project progress and developing findings. Formal methods included MP and the BJO Rangers analyzing and discussing themes arising from a subset of the first Bardi Jawi interviews. On several occasions rangers copresented with MP at conferences, stimulating collaborative development and refinement of communications about the research findings (presentations), including a review of the conceptual framework, also facilitating clarity of process and the required etiquette for sharing indigenous knowledge in public realms. Similarly, each ranger team collaboratively reviewed drafts of this paper. Also, several Bardi Jawi elders (coauthors) acted as cultural mentors, providing feedback on the project, e.g., methodological process, and iterative findings, e.g., themes for the participatory review and drafts of the conceptual framework and this paper. Hence, although the conceptual framework has been primarily interpreted and communicated by MP as lead researcher, feedback from participants and indigenous ranger and elder coresearchers has consistently contributed to and validated research findings.

Participatory action research (PAR) seeking to generate positive research experiences, benefit participating indigenous groups and build the capacity of all involved (Maclean and Woodward 2013, Woodward and Marrfurra McTaggart 2015) informed the research methodology. With their foundations in decolonizing research, participatory approaches attempt to break down embedded power imbalances that privilege conventional paradigms within cross-cultural work (Howitt and Stevens 2010, Tuhiwai Smith 2012). To position indigenous perspectives, knowledge, and preferences as central to this project's design, indigenous participants and coresearchers contributed to its conception, planning, implementation, and dissemination of findings (see Adams et al. 2014), as already described. Tangible benefits for research participants included a hardcover book containing photos and summarized interviews, plus the ranger groups paid participants for their contributions according to the research aligning with local work plans. The books (including drafts circulated among participants for their review), depicting photographs, maps of site locations, and summarized interviews, also helped participants to better understand the purpose of the research, enhancing their informed consent, catalyzing more feedback, and improving research accountability. By engaging rangers as coresearchers we sought not only to document indigenous knowledge but also build ranger team capacity for independent research and management of wetlands in a way that engages with their communities and their knowledge systems.

\section{RESULTS}

Here we present and describe the key beliefs (inner blue circle, Fig. 2), principles (orange circles), and their expression (white circles) that make up the conceptual framework depicting the Bardi Jawi and Nyul Nyul wetland management system (Fig. 2). We first describe three beliefs; country has agency, country is related to people, and country needs people, which provide a foundation for understanding human-wetland relationships and interactions. We next describe four principles; custodianship, respectful use, active maintenance, and learning, including some of the ways in which these principles are expressed, through which beliefs are embodied and enacted within human-wetland interactions. Last, we explore how, through these beliefs, principles, and their expressions the Bardi Jawi and Nyul Nyul people engage in a system of wetland management that has purpose and structure.

\section{Beliefs underlying human-wetland relationships}

\section{Country has agency}

In simple terms, "country has agency" means that country can take independent action. This was evident through participants' belief that the supernatural forces that compose country can react positively and negatively to the actions of humans. Fundamentally, participants believe that country intentionally provides for people, both the traditional owner family group (those with specific cultural affiliations to an area) but also to any human, as one elderly Bardi Jawi woman explained in relation to a biidin (see Table 1): "Spiritually the water was there to look after our thirst. We believe it was there for us to use and benefit."

However, this act of giving is contingent on respectful and appropriate human behavior. For example, Bardi Jawi participants explained in relation to groundwater sources (biidin and oomban, see Table 1) that country will provide freshwater (that is, good quality water can be found in the ground) if people behave with respect and refrain from actions such as loud and 
Table 3. Coding frame used to analyze all qualitative data (interview transcripts, observational notes, and transcripts of meetings).

\begin{tabular}{|c|c|}
\hline Theme & Subthemes or explanation \\
\hline Beliefs & $\begin{array}{l}\text { Reference to beliefs regarding the human-nature relationship, or causes of } \\
\text { environmental phenomena related to wetlands }\end{array}$ \\
\hline Ownership & Reference to custodial relationships with wetlands \\
\hline Rules and respect & $\begin{array}{l}\text { Reference to rules or norms regarding human-nature relationships, } \\
\text { including any reference to respectful behavior }\end{array}$ \\
\hline Use & Ceremony and Law \\
\hline \multirow[t]{7}{*}{ (ways that wetlands are used, or contexts in which wetlands are used) } & Ranger work \\
\hline & Holidays \\
\hline & Camping, fishing, hunting, gathering \\
\hline & School \\
\hline & Mustering (rounding up cattle) \\
\hline & Life (drinking water, bore water) \\
\hline & Travel \\
\hline \multirow[t]{3}{*}{ Wetland management practices } & Cleaning \\
\hline & Practice (excluding cleaning) \\
\hline & Nigilbuninj \\
\hline \multirow[t]{7}{*}{ Methods of learning } & Environmental observation \\
\hline & Dream \\
\hline & Family \\
\hline & Story \\
\hline & Ranger program \\
\hline & Use or work \\
\hline & Learning language words \\
\hline
\end{tabular}

unruly behavior and dropping rubbish. This was demonstrated by the actions of a Bardi Jawi woman:

[A] was calling out for [B] to come and dig the oomban, but $[B]$ was off getting oysters off the rock. Eventually [A] set off to dig it herself. She scooped out a hole in the sand with an enamel mug and her hands, working quite gently and asking the place and the old people [spirits of ancestors] there to give her fresh water. She kept sipping the water, exclaiming "Mmm getting close" if the water was tasting less salty, or "They' re getting wild" [meaning the spirits of ancestors were becoming discontented] when the water tasted more salty. At one point [a young ranger] came over but [her behavior was quite loud and brash] ... which [A] thought would make the ancestors wild.

The agency of country is particularly evident at powerful water places, described by both Bardi Jawi and Nyul Nyul participants as those places associated with ceremonial (law) grounds or creator-spirits. People are prohibited from entering several of these areas (unless under the direction of senior law men), whereas at others particular acts are prohibited. As described by a Nyul Nyul Ranger, these sites can inflict harm on humans who wrongly enter them or carry out a prohibited act:

And there's a rainbow serpent living in [X]. There is a
story that a priest went to that waterhole, he was looking
for something, a horse got stuck or something, and he got
stuck down there. The old people say the rainbow serpent
got him. He never came back up.

Other sites are associated with raya (spirit-children), which can choose to hide water or make it unavailable, unless visitors act respectfully and according to cultural protocols.

Nyul Nyul participants described two other elements of country that are involved in the ongoing creation and health of springs.
Four participants cited one wetland as being particularly important to Nyul Nyul country. They described how a creator spirit resides in this spring and the spring provides the spiritual source of health of the surrounding water places. Also, most Nyul Nyul participants recognize the role of nigilbuninj (freshwater eel or Anguilla bicolor) in the creation of new springs. Nyul Nyul participants discussed how historically their elders enforced restrictions on nigilbuninj fishing, to avoid overfishing and any impact this might have on spring creation. Although no longer a primary food source, nigilbuninj is still considered central to spring creation. Thus, for Nyul Nyul people, a healthy spring ecosystem rests on the presence, condition, and actions of (at least) one key wetland and nigilbuninj.

Country is related to people

Bardi Jawi participants described direct (custodial) relationships existing between water places and particular individuals or family groups. The most commonly discussed were genealogical or ancestral links to a booroo. That is, an individual is connected to the same country (and water places) as their parents, grandparents, and so on, as described by a senior Bardi Jawi woman in relation to an oomban: "It belong[s] to us, the old people ... Mum was the last one left, passed on, the water is still there, left it for us, grandkids, future kids."

Relationships also exist between people and spirits, some belonging to ancestors that have passed away, their spirit returning to reside in their country. These spirits, often referred to as "old people," can respond favorably to the presence of their descendants on country, or even to the presence of any person who engages in respectful use and other appropriate behavior, for example, engaging with correct access protocols/rules and active maintenance practices. Many participants also described a responsibility to act respectfully toward their entire language group's country, as expressed by a Nyul Nyul Ranger: 
With any Aboriginal place you go to, you've got to follow the rules you know... Here you just [have] to talk to the old people this side of the country, you know. Tell them what you're here for...

Country needs people

Bardi Jawi and Nyul Nyul people discussed how the relationship between country and people is crucial to country flourishing. The "aliveness" of Country relies on the physical presence and activities of people, in particular traditional owners making use of country's resources. A long absence of traditional owners was attributed as the cause of declines or changes within country including the closing (covering over with beach sand), disappearance, or excessive growth of plants across some surface and ground water places. Reasons for such decoupling of productive human-wetland relationships included traditional owners passing away or younger generations no longer visiting or engaging in appropriate use of sites. For example, one elderly Nyul Nyul man perceived that country had irreversibly retracted resources from Nyul Nyul people because of what he saw as a lack of local interest in certain customary activities:

... We used to have water, spring waters, [but] they all covered up now... all them days are gone now. It's [a] new life now, young people life.

MP: How have those springs changed?

Springs must be all finished now, finish. Springs were all

finished...they all covered up. Mother Nature get them you know.

MP: Did you catch eel, nigilbuninj, when you were young too?

Yeah but they small now, they nothing. You can't get 'em no more. We used to live on them you know. This time now it's nothing.

On the other hand, several participants explained that changes to country are not necessarily permanent; if traditional owners return to country it may rejuvenate even without any specific action by its owners.

\section{Principles guiding wetland interactions}

\section{Custodianship}

Custodianship was evident through participants' comments and their expectations for how interviews should be conducted. Generally expressed as an ancestral-genealogical relationship between families or individuals and water places on their country, custodians, or traditional owners, hold responsibility for the proper maintenance, management, and use of water places. For example, both ranger groups expected MP to identify traditional owners and, with their permission and participation, visit water places for interviews. Most (20) Bardi Jawi people chose to visit and speak about a water place on their booroo, and about half (all ages) associated meaning or importance with traditional ownership, that is, a water place belonging to their family, as described by a senior Bardi Jawi man:

What this place means to me is that, when I was a little kid growing up I was told by my grandparents that this was our country, this belongs to us and they came from here, my grandfathers came from here. And ... my fathers also toldme, that this land belongs to us. That's why we're here today. We built on this land because, knowing that it belongs to us, and everything around here is part of us, part of our dreaming.

Bardi Jawi and Nyul Nyul elders sometimes described genealogical site linkages to younger rangers during visits, explaining connections between individuals and places. Participants emphasized that permission for physical site management (such as digging waterholes), must be granted by traditional owners. More broadly, however, both Bardi Jawi and Nyul Nyul participants described a custodial responsibility for water places beyond their family-affiliated territories/booroos to encompass the entirety of their respective language groups' country.

Meaningful and knowledgeable relationships between people and water places were also expressed outside custodianship. Changing lifestyles have provided Nyul Nyul and Bardi Jawi people with different opportunities to interact with water places over time. For example, many elders interviewed grew up in one of several religious missions that operated in the region throughout the 1900s. During mission-life, some elders, particularly women, were prevented from travelling distances but permitted visits to nearby water places. Conversely others, including men engaged in the rounding up of cattle, travelled widely across the Dampier Peninsula and visited many water places. As such, some Bardi Jawi and Nyul Nyul participants chose to visit and speak about water places on another person's country, if they felt more familiar and knowledgeable about that place. However, these individuals did not claim custodial/traditional ownership.

Respectful use

Senior and elderly participants desire that new generations continue to know about, use, and maintain water places in a respectful way. Bardi Jawi and Nyul Nyul elders described that respect is initiated when individuals approaching a site introduce themselves to the water place, generally verbally, but also through their touch, such as placing a hand on the ground. Individuals are also expected to abide by norms and rules about restricted areas and prohibited activities. Other efforts that were described or observed by MP included avoiding "humbug" around water places, such as children misbehaving, complaining, or yelling, or adults littering. Abiding by custodianship protocols was also important, including seeking permission from traditional owners before visiting or making physical changes at a water place. One ranger also described a broader concept of respect that involved retaining and using cultural knowledge and language.

Many Bardi Jawi and Nyul Nyul men and women described visiting and using water places when travelling for fishing, camping, hunting, or gathering bush foods, particularly during school holiday times. Some participants referred to these customary activities as the "right way" to use country, as explained by a senior Bardi Jawi woman:

Interviewer [Ranger]: Were there any ways that the old people looked after this place in the past?

Yes they looked after in a lot of ways. Because they used it right way, and they used to hunt and gather food and bush fruits, and they used to live in their areas. You all can see the middens here, the shell, they must have had 
a lot of things there and making sure that everything was good on their country and they were happy.

The elderly Nyul Nyul man referred to earlier stressed that, in the past, the use and management of country was "automatic" in the sense that cultural beliefs, behaviors, and ideas were so central to everyday life that they required no planning or forward thinking. In his view, it is clear that country will decline and be unproductive without the human enactment of necessary cultural activity to sustain it. He lamented the major cultural shifts he had observed that mean young people are now engaged in other pursuits, particularly making money, rather than living more directly from country, and perceived little chance of reviving past ways of life.
MP: .... [P] ]eople have told me these areas over here have changed. Can you remember what it used to be like... and has it changed?
It was the good old days you know. They were the golden days. Now it's nothing. You don't see nothing now ...
MP: Do you think there were ways, or can you remember ways, that people were maybe looking after the bush back then?
Well people always looking after the bush because they used to eat the bush tucker you know ...
MP: ... For water places, did people...
Too late, too late you come... All finished. The good old days are finished...
MP: Did you see people like cleaning water places when you were young? ...
No they just keep it clean all the time. The old people used to keep it neat.
MP: How did they do that? ...
... It'd be automatically for me you know. You come now too late... [W]e used to live on them you know, in our days, bushtucker and things. This time there's nothing, you get paid now.

Water places are no longer relied upon for survival. Some water places are not currently used and others are used less so, or differently, to the past. Despite this, we observed or learned that many water places remain in regular use. Both elders and younger participants desire that the use of some (disused or underused) water places be rekindled, such that freshwater is available for humans and animals, and such that their active use and maintenance enacts respect for the metaphysical beings (such as spirits of ancestors) associated with these places.

\section{Active maintenance}

Bardi Jawi and Nyul Nyul participants, particularly senior and elderly people, described methods of maintaining or "cleaning" wetlands that were practiced in the past, and, at some locations, continue within the context of social and environmental change in the present. Controlling plant growth inside and around some ground and surface water places, e.g., water holes and springs, either by physically pulling out riparian or aquatic plants, or using small fires was among the spectrum of activities, having the purpose of maintaining water flow, quality (temperature, clarity, taste) of drinking water sources, and cleaning water sites. After wetland cleaning stopped, some water places have become overgrown with plants, with some sites construed as unclean, as explained by an elderly Nyul Nyul traditional owner:

\begin{abstract}
MP: Were there any ways that the old people looked after this place in the past?

Ancestors would look after the spring. After we left in the 50s and nothing was happening, anybody would go around here, fishing for nigilbuninj. Now it's all covered up... [We should] keep the pools but get rid of the muck and rubbish [bulrushes, reeds, some trees].
\end{abstract}

In addition to promoting freshwater flow, improving water quality for drinking, and maximizing open water, wetland maintenance also serves (now and in the past) as a way to respect and maintain the metaphysical aspects of country, as one senior Nyul Nyul man explained:

Like I say, sometimes when we used to use areas for swimming we'd go in there and clean it all out. Yep. Because, in most of this country, most of these areas where freshwater was, our belief, through our spiritual belief and culture, is that ... there were rayas in it, we call it little people. So they also used to be around these areas, alright? In our cultural belief. So we had to maintain these areas of cleanness and tidiness yes, to make sure that it was, it was not only for us [humans] that we could have fresh water or clean water to drink, but it was also for the little people that were there, [the] spiritual people. You know, make the place look clean. It's our respect to the land. You have to respect that. And this is how we were taught, yeah. That's how we were taught, to respect country.

Examples of present day water-place management include efforts by ranger teams to dig out and remove built-up sand within groundwater wells to maintain access to groundwater, and strategic burning to prevent wildfires destroying riparian vegetation. Catalyzed through this research, the Bardi Jawi Rangers also facilitated custodians (a traditional owner family) to visit and clean up one wetland that was perceived to be overgrown with vegetation.

\section{Learning about wetlands}

Types of important knowledge about water places encompass interrelated domains pertaining to the physical environment, institutions, and metaphysical and ethical dimensions, including cultural rules. The physical environmental dimension includes knowledge about the following: plant and animal species that live in and around wetlands, and have a myriad of cultural uses and values; the names, location, characteristics, and functioning of water places; and knowledge of how to find freshwater in an unfamiliar environment. Institutional knowledge includes an understanding of family structures or genealogies, through which individuals are associated with particular countries and therefore wetlands, and related cultural protocols for respectfully accessing sites. Metaphysical and ethical knowledge relates to the presence of spiritual beings, the location of sacred wetlands that cannot be accessed, or rules relating to whether visitation or certain activities are prohibited.

Bardi Jawi and Nyul Nyul participants described different ways and contexts in which they have been educated about water places. Many participants learned about the location and use of water places through family members, in particular during school holiday periods. After the advent of formal schooling, initiated 
by religious missions, both Bardi Jawi and Nyul Nyul people would send their children back to country for school holidays, often to spend time with grandparents. Families spent school holidays fishing, camping, and generally living on country, including using, and teaching children about, water places. During time spent on country or otherwise, stories shared can also convey important information about wetlands. Employment that facilitates time on country also provides opportunities for learning. For example, several male participants learned about and used water places while travelling with elder family members to round up cattle. The ranger program provides a contemporary context within which rangers and other members of the Bardi Jawi and Nyul Nyul communities can engage with wetlands either through research (such as this project) or specific management activities. Participants from both groups also described how new freshwater places can be learned about by observing environmental cues.

\section{DISCUSSION}

Bardi Jawi and Nyul Nyul people have an organized and skilled way of understanding wetlands and their treatment, which can be construed as culturally specific systems of wetland management. Particular practices, institutions, and norms vary, being rooted in culturally specific knowledge, beliefs, practices, and language, and different environmental contexts. Therefore one indigenous group's wetland management system is specifically associated with that group's ancestral lands and cultural system, and cannot be generalized and applied elsewhere. However, there are conceptual similarities in how Bardi Jawi, Nyul Nyul, and other indigenous people's interacting beliefs, practices, and knowledge manifest to guide the purpose and organization, and related learning, about wetlands and their management.

Although conventional (academic science-based) ways of managing wetlands are well known (see, for example, Boulton et al. 2014), parallel indigenous systems are not. By making these systems, their elements, and their interconnections explicit, the Bardi Jawi and Nyul Nyul framework potentially facilitates greater engagement with the complexity of IKSs within wetland management. By linking Bardi Jawi and Nyul Nyul systems of logic (macro-scale) with water places, including some of the plants and animals within them (microscale), the framework offers an intermediary (meso) scale particularly relevant to understanding the ideas and practices underlying wetland management. We subsequently expand on the purpose or meaning, organization, and systems of learning underlying Bardi Jawi and Nyul Nyul wetland management, reflecting on similarities with other indigenous nations. Understanding such features could contribute to the deep reflection required within cross-cultural collaborations to generate a more complex and inclusive understanding and practice of wetland management (see Rogers et al. 2013). Adding to this, we also consider how indigenous wetland management shapes ecosystem services and, finally, offer ideas for interpreting the framework to further research into indigenous and collaborative wetland management.

\section{The meaning of indigenous wetland management}

The concept of wetland management has multiple meanings for Bardi Jawi, Nyul Nyul, and other indigenous groups, relating to physical, social, and metaphysical dimensions of these ecosystems. Through various practices and activities, Bardi Jawi and Nyul Nyul people seek to facilitate wetland productivity and cultural opportunities (as in Tipa and Nelson 2008), while respecting and satisfying the metaphysical dimensions and social structures affiliated with country. Studies of Aboriginal values of freshwater consistently describe traditional owner obligations to undertake practices that simultaneously engender respect for metaphysical beings and promote particular wetland characteristics, processes, biota, and functionality (e.g., Strang 1997, Yu 1999, Toussaint et al. 2001). In contrast, studies in India (Singh 2006) and New Zealand (Kahui and Richards 2014) relate indigenous wetland management to a rational, rules-based approach to meeting resource requirements. However, Singh (2006) concludes that indigenous Indian water management is not purely based on rational assessments of material or economic costs, benefits, and need. Rather, it is " .... mechanism to maintain and reinforce the cosmological constructions linking natural, supernatural, and social orders through water" (Singh 2006:364). Similarly, in New Zealand, Kawharu (2000) contends the distinguishing feature of Maori environmental management is its “...structural principle which weaves together a triadic relationship between human beings, their environment and the spiritual realm" (Kawharu 2000:367). It is this indivisibility of the cultural, social, philosophical, and intellectual from the physical elements of IKSs that also characterizes Bardi Jawi, Nyul Nyul and other indigenous people's paradigms of wetland management (Langton 2006, Lansing 2007, Strang 2009b).

Practical indigenous efforts to manage wetland processes, biota, and functionality also have a physical, social, and metaphysical purpose. For example, historically Nyul Nyul people placed harvest restrictions on freshwater eels, a valued food source, to avoid their exploitation. Although harvest restrictions supported long-term resource availability, this action may have also helped to maintain an environmental balance in which eels are culturally associated with the regeneration of springs. Cleaning wetlands to maintain accessibility and water quality, alongside the value of sustaining and enacting traditional beliefs and practices within the context of cultural and environmental change to ensure lands and waters are protected, is widespread across Australian Aboriginal groups (Rea and the Anmatyerr Water Project Team 2008, Walsh 2008, Jenkin et al. 2009, McGregor et al. 2010, Preuss and Dixon 2012). The primacy of satisfying the metaphysical dimensions of country means that some Aboriginal activities construed as management are not akin to conventional activities. Principally, Aboriginal management requires the active presence and respectful use of country through hunting, fishing, use of materials, ceremonial activities, and so on. According to Strang (1997) the significance of these activities is the re-enacting of traditional lifestyles that began with creator-spirits, which one Bardi Jawi woman described as using country the "right way" and a Nyul Nyul man described as "automatic." Although Aboriginal groups continue to grapple with historical and ongoing cultural change, and many ways of maintaining wetlands have declined or changed (for example, see Walsh 2008), Bardi Jawi, Nyul Nyul, and others (e.g., White et al. 2011) wish to see some practices strengthened or revitalized. Many such practices are communal, involving multiple members of a clan or family that reflect custodial structures and a type of management organization. 


\section{The organization of indigenous wetland management}

Indigenous land (and wetland) management operates at different scales, with individuals, families, and groups or clans holding responsibility for the management of specific wetlands. At a broad level, Kimberley Aboriginal groups express collective responsibilities for wetlands within the country that is affiliated with their language or tribal group as a whole (e.g., Yu 1999, Barber and Rumley 2003). Within this collective perspective, finer-scale expressions of custodianship also arise. For example, within their native title area, Bardi Jawi families have affiliations with, and responsibilities for, their booroos and the wetlands within them. Within Bardi Jawi family groups decision-making authority for wetland management activities is then further delegated to particular individuals. Similarly, smaller areas within Nyul Nyul Country, including wetlands, are affiliated with particular traditional owner family groups or individuals. In another example, for the Aboriginal people of the La Grange area in the south Kimberley, jila (permanent water places) belong to senior lawmen, who hold the responsibility and knowledge for their maintenance (Yu 1999). Such spatial organization and affiliated custodial responsibilities existed among Aboriginal groups Australia-wide prior to European settlement (Strang 2009b, also see Langton 2006).

Social structures underlying wetland management exist and have meaning outside of Australia. For example, in British Columbia, Canada, Haggen and colleagues describe how indigenous stewardship of salmon relies on "nested tenure systems" (Haggen et al. 2006:19). Family groups and individuals within clans conducted fine-scale management of rivers and tributaries to maximize fish productivity, with the tenure system endowing both resource access rights and responsibility for management (Haggen et al. 2006). Maintaining systems of rights and responsibility for the use and management of wetlands relies on learning a broad knowledge base.

\section{Learning about wetland management}

The interlinking of active wetland maintenance with beliefs, ethics, and custodial structures requires maintaining knowledge pertaining to physical, metaphysical, and social realms. Ways of learning and sharing knowledge are common across the Kimberley region. Knowledge is gained, for example, through observing environmental phenomena, spending time with family on-country in practical customary pursuits, learning from others through stories, engaging in ceremony, and received in dreams (Toussaint et al. 2001, 2005). Most of this learning relies on direct interaction with the environment or gaining knowledge from family and other members of the community, systems of education that also exist within other indigenous communities (Rea and the Anmatyerr Water Project Team 2008, PaniaguaZambrana et al. 2016).

The transition of indigenous groups away from customary ways of life to mainstream lifestyles (such as living in towns and participation in formal systems of education and economy) has altered engagement in cultural education systems (Strang 1997, Reyes-García et al. 2014). For example, research with indigenous peoples of South America found that formal schooling (ReyesGarcía et al. 2010), lowered dependence on traditional resources, and exposure to new technology (Paniagua-Zambrana et al. 2016) were associated with the loss of some types of cultural knowledge among younger generations. However, despite significant lifestyle changes Bardi Jawi, Nyul Nyul, and other indigenous groups have embraced new opportunities to share and maintain knowledge about wetlands. Economic activities that foster continued application of cultural skills can facilitate knowledge maintenance (Goodall 2008). Indigenous NRM offers opportunities for indigenous people to engage with, apply, and revitalize IKSs as it relates to wetland management (e.g., McGregor et al. 2010, Dobbs et al. 2016). However, many projects fail to engage with the full complexity of IKSs and, instead, perpetuate conventional knowledge systems (Howitt and SuchetPearson 2006, Barbour and Schlesinger 2012, Muller 2012). Maintaining IKSs can benefit indigenous knowledge-holders (Reyes-García et al. 2010), but also has important potential environmental benefits (Ens et al. 2016). Evident through the Bardi Jawi and Nyul Nyul conceptual framework is that wetlands not only support ecosystem services of importance to traditional owners, but that those groups also shape ecosystem characteristics, providing "services to ecosystems" (Comberti et al. 2015).

\section{Promoting indigenous wetland management and "services to ecosystems"}

Ecosystems, including wetlands, provide vital services, or benefits, to humans (Boulton et al. 2014, Bark et al. 2015); however, Comberti et al. (2015) argue that equally important are the services provided by humans to ecosystems ("services to ecosystems" or S2E). Similarly, the Ramsar Convention on Wetlands (Ramsar Convention) recognizes that indigenous people's practices and activities can contribute positively (and also negatively) to maintaining wetland ecological character, including ecosystem services (Pritchard et al. 2016). The Bardi Jawi and Nyul Nyul framework exemplifies both ecosystem services and S2E. For example, wetlands provide ecosystem services such as drinking water, valued food species and materials, and places and species that are central to cultural beliefs and identity. In turn, Bardi Jawi and Nyul Nyul people's interactions with and management of wetlands potentially enhance the availability of surface water sources, improve freshwater quality, and enhance aquatic heterogeneity and productivity.

That indigenous wetland management can shape both S2E and the quality of ecosystem services has important implications for conservation and human well-being. Ecosystem services include those that sustain biophysical systems necessary for human life (provisioning, regulating, and supporting services) and those that sustain nonmaterial benefits (cultural ecosystem services) including cultural identity; aesthetic, heritage, and spiritual values or experiences; inspiration; recreation and tourism; social relations; and knowledge systems (Millennium Ecosystem Assessment 2005, Chan et al. 2011). Indigenous people's management of, or services to, wetlands can contribute to sustaining desired cultural ecosystem services (as we have demonstrated) as well as biophysical ecosystem services that can enhance ecological outcomes such as biodiversity conservation (McGregor et al. 2010, Hankins 2013). For example, in different parts of southeastern Australia, Aboriginal people historically modified wetlands to regulate or augment eel populations that were a valued food species (Lourandos 1980, Builth et al. 2008). In another example, indigenous alpaca herders of the Central Andes, Peru, use irrigation techniques to maintain and expand 
wetland areas and support their herds, with their practices sustaining around $40 \%$ of their locality's biodiverse, high altitude wetlands (Verzijl and Quispe 2013). Encouraging or supporting indigenous groups to enact or revitalize S2E and enhance ecosystem services may generate new, or strengthen existing, human-ecological benefits (Moritz et al. 2013, Verzijl and Quispe 2013, Rose et al. 2016). Maintaining the health, integrity, and continuity of IKSs therefore becomes central to ecosystem condition (Comberti et al. 2015, Pert et al. 2015).

Bardi Jawi and Nyul Nyul people's ways of managing wetlands, as highlighted through the conceptual framework (Fig. 2), constitute a system that differs from, and coexists alongside, conventional perspectives (see Nursey-Bray and Arabana Aboriginal Corporation 2015). Beyond the significant, often traumatic, changes wrought upon many colonized indigenous societies is their challenge to simultaneously engage with specific local and mainstream social and cultural systems. For example, the shift from living around wetlands and relying on their use for daily survival to, for many Bardi Jawi, Nyul Nyul, and other Aboriginal people, living in towns and engaging with modern economies, precludes much "automatic" daily wetland use and maintenance, and related opportunities for direct and incidental in-situ learning. However, in the context of cultural and environmental change wetland use continues and, as we have discussed, expectations remain that wetland management principles and their expressions (Fig. 2) are continued, strengthened, or revitalized. Collaborative wetland management and research offers the opportunity to better understand related benefits for both people and ecosystems, and effectively support indigenous wetland management. Interpreting the conceptual framework offers a first step in identifying how collaborative wetland research or management can be more fully informed by, and engage with, complex Bardi Jawi, Nyul Nyul (or other indigenous) knowledge systems. By generating or guiding questions and conversations the conceptual framework could help nonindigenous project partners to learn about their indigenous coresearchers' knowledge system. From a basis of mutual understanding, many opportunities then exist for indigenous beliefs, knowledge, and practices to shape collaborative wetland research and management activities.

Principally, the conceptual framework demonstrates that wetlands cannot be viewed as ecosystems isolated from humans, but as places intimately related to custodial individuals and families. Respecting these custodial institutions and related protocols would elevate custodians (individuals and families) as project partners, requiring attention to their aspirations, practices, and theories for ecological work and appropriate human-wetland interactions, as well as their active participation (e.g., Rea and the Anmatyerr Water Project Team 2008, Fox et al. 2017). Past (and ongoing) custodial use and management likely represent an important ecological influence (for example, see Humphries 2007), with indigenous people's recollections of historical wetland condition and character potentially revealing important reference conditions, which may only be recreated through local scale Aboriginal practices or direction. Upon respectfully interpreting past (and continuing) active maintenance practices, such practices could be supported, aided by empirical research to assess humanecological outcomes using both standard quantitative measures as well as appropriate qualitative methods (e.g., Tipa and Teirney 2006, Tipa and Nelson 2008, McGregor et al. 2010). While undertaking such work, maintaining knowledge could involve generating and actively using a shared language that involves indigenous terminology for aquatic species, places, and other ecological phenomena, as well as local concepts of wetland management (sensu Rea and the Anmatyerr Water Project Team 2008, Muller 2012, Londono et al. 2016). All of these efforts would benefit from ethnographic studies to provide a foundation for communication between indigenous and nonindigenous project partners (Jackson and Douglas 2015). Further research could also inform how respectful use of wetlands fosters the continuation of wetland management principles (Fig. 2) and S2E. In this regard, others have found that customary use of natural resources is directly linked to maintaining cultural knowledge, institutions, and biodiversity (e.g., Singh et al. 2013, Ligtermoet 2016, Paniagua-Zambrana et al. 2016).

Full engagement with IKSs requires a significant investment in collaborative efforts and a potential transformation of standard research methods (see Hill et al. 2012, Tengö et al. 2017). Factors in our research encouraging fruitful collaboration that others have also found important included extended research timelines (at least three to four years), regular activities and dialogue on country (at wetlands), and a strong and positive commitment by both nonindigenous and indigenous research leaders (see Woodward and Marrfurra McTaggart 2015). Importantly for MP, living and participating in local community life for four years gradually enabled her own personal knowledge transformation to comprehend IKSs (as in Gratani et al. 2011).

Overall, the holistic, active, and integrated nature of IKSs and associated practices must be recognized and respectfully adapted within ecosystem management (Turner et al. 2000, Horstman and Wightman 2001, Bark et al. 2015). Such indigenous knowledge systems offer (at least) the potential for multiple evidence-based approaches to wetland management challenges (as in Tengö et al. 2014), but also the potential for a more fundamental reexamination of the principles that can foster enduring, sustainable human-wetland relationships.

\section{CONCLUSION}

Substantial research that involved the Bardi Jawi and Nyul Nyul peoples demonstrate that, as with others living in parallel circumstances, each group engages in specific systems of wetland management within the context of continuity and cultural change. Similarities in the purpose, organization, and ways of learning about wetland management exist among indigenous groups worldwide, although specific expressions (practices, norms, cultural institutions, etc.) differ. IKSs, shown here as a system of wetland management, should be viewed as complex conceptual and active paradigms in which physical, social, and metaphysical realms are highly integrated as a means to both activate and benefit ecosystems.

Evidence points clearly to cross-cultural wetland research and management prospering when active and respectful engagement with all aspects of indigenous systems of wetland management occur. The Bardi Jawi and Nyul Nyul conceptual framework provides a visual tool for communicating to scientists and NRM practitioners how IKSs relate to managing wetlands. The framework described may not only assist Bardi Jawi and Nyul Nyul people to negotiate for their own interests, perspectives, and strategies in managing wetlands, but other wetland communities as well. 
Responses to this article can be read online at: http://www.ecologyandsociety.org/issues/responses. $\mathrm{php/10283}$

\section{Acknowledgments:}

The language and information contained in this publication includes Aboriginal Cultural and Intellectual Property of the Bardi Jawi and Nyul Nyul peoples, published with their consent. We wish to thank the Bardi Jawi and Nyul Nyul people, especially the elders and traditional owner families who participated, for their generous contributions of knowledge, time, and access to traditional lands they provided throughout this research. We are grateful to all of the Bardi Jawi Rangers, Bardi Jawi Oorany Rangers, and Nyul Nyul Rangers for their assistance in conducting the research, and to the Ranger coordinators, managers, and cultural advisors for their valuable support including Kevin George, Ingrid Elmitt, Phillip Mc Carthy, Daniel Oades, Damon Pyke, Mark Rothery, and Debbie Sibosado. Thank you to Will Davis from the Kimberley Land Council for providing the map. At the time of the study the first author was a recipient of an Australian Government Research Training Program Scholarship and a University of Western Australia top-up scholarship. Thank you also to the following organizations that supported either Michelle's or Rangers' attendance at conferences in Australia and New Zealand including: Convocation of UWA Graduates, UWA Graduate Research School, UWA Postgraduate Students Association, Ecological Society of Australia, and the Australian Freshwater Sciences Society (formerly Australian Society for Limnology). A grant generously provided by the Ronald and Catherine Berndt Research Foundation supported the design and printing of the photo-books provided back to Bardi Jawi and Nyul Nyul families.

\section{LITERATURE CITED}

Adams, M. S., J. Carpenter, J. A. Housty, D. Neasloss, P. C. Paquet, C. Service, J. Walkus, and C. T. Darimont. 2014. Toward increased engagement between academic and indigenous community partners in ecological research. Ecology and Society 19(3):5. http://dx.doi.org/10.5751/ES-06569-190305

Aklif, G. 1999. Ardiyooloon Bardi ngaanka: One Arm Point Bardi dictionary. Kimberley Language Resource Centre, Halls Creek, Western Australia, Australia.

Australian Institute of Aboriginal and Torres Strait Islander Studies (AIATSIS). 2011. Guidelines for ethical research in Australian indigenous studies. AIATSIS, Canberra, Australian Capital Territory, Australia.

Barber, K., and H. Rumley. 2003. Gunanurang: (Kununurra) big river. Aboriginal cultural values of the Ord River and wetlands. A study and report prepared for the Water and Rivers Commission. Perth, Western Australia, Australia.

Barber, M., and S. Jackson. 2014. Autonomy and the intercultural: interpreting the history of Australian Aboriginal water management in the Roper River catchment, Northern Territory. Journal of the Royal Anthropological Institute 20 (4):670-693. http://dx.doi.org/10.1111/1467-9655.12129
Barbour, W., and C. Schlesinger. 2012. Who's the boss? Postcolonialism, ecological research and conservation management on Australian indigenous lands. Ecological Management \& Restoration 13(1):36-41. http://dx.doi.org/10.1111/j.1442-8903.2011.00632. $\underline{\mathrm{X}}$

Bark, R. H., M. Barber, S. Jackson, K. Maclean, C. Pollino, and B. Moggridge. 2015. Operationalising the ecosystem services approach in water planning: a case study of indigenous cultural values from the Murray-Darling Basin, Australia. International Journal of Biodiversity Science, Ecosystem Services \& Management 11(3):239-249. http://dx.doi.org/10.1080/21513732.2014 .983549

Berkes, F., and M. K. Berkes. 2009. Ecological complexity, fuzzy logic, and holism in indigenous knowledge. Futures 41(1):6-12. https://doi.org/10.1016/j.futures.2008.07.003 http://dx.doi.org/10.1016/ j.futures.2008.07.003

Berkes, F., J. Colding, and C. Folke. 2000. Rediscovery of traditional ecological knowledge as adaptive management. Ecological Applications 10(5):1251-1262. http://dx.doi. org/10.2307/2641280

Bohensky, E. L., and Y. Maru. 2011. Indigenous knowledge, science, and resilience: what have we learned from a decade of international literature on "integration"? Ecology and Society 16 (4):6. http://dx.doi.org/10.5751/es-04342-160406

Boulton, A. J., M. A. Brock, B. J. Robson, D. S. Ryder, J. M. Chambers, and J. A. Davis. 2014. Australian freshwater ecology: processes and management. Second edition. John Wiley \& Sons, Ltd., Chichester, UK.

Bowern, C. 2009. Naming Bardi places. Pages 327-345 in H. Koch and L. Hercus, editors. Aboriginal placenames: naming and renaming the Australian landscape. ANU E Press and Aboriginal History Incorporated, Canberra, Australian Capital Territory, Australia. http://dx.doi.org/10.22459/AP.10.2009.15

Builth, H., A. P. Kershaw, C. White, A. Roach, L. Hartney, M. McKenzie, T. Lewis, and G. Jacobsen. 2008. Environmental and cultural change on the Mt Eccles lava-flow landscapes of southwest Victoria, Australia. Holocene 18(3):413-424. http://dx. doi.org/10.1177/0959683607087931

Calheiros, D. F., A. F. Seidl, and C. J. A. Ferreira. 2001. Participatory research methods in environmental science: local and scientific knowledge of a limnological phenomenon in the Pantanal wetland of Brazil. Journal of Applied Ecology 37 (4):684-696. http://dx.doi.org/10.1046/j.1365-2664.2000.00524.x

Chan, K. M. A., J. Goldstein, T. Satterfield, N. Hannahs, K. Kikiloi, R. Naidoo, N. Vadeboncoeur, and U. Woodside. 2011. Cultural services and non-use values. Pages 206-228 in P. Kareiva, H. Tallis, T. H. Ricketts, G. C. Daily, and S. Polasky, editors. Natural capital: theory \& practice of mapping ecosystem services. Oxford University Press, New York, New York, USA. http://dx. doi.org/10.1093/acprof:oso/9780199588992.003.0012

Choo, C. 1997. The role of the Catholic missionaries at Beagle Bay in the removal of Aboriginal children from their families in the Kimberley region from the 1890s. Aboriginal History 21:14-29. 
Close, P. G., J. Wallace, P. Bayliss, R. Bartolo, D. Burrows, B. J. Pusey, C. J. Robinson, D. McJannet, F. Karim, G. Byrne, S. Marvanek, C. Turnadge, G. Harrington, C. Petheram, L. X. C. Dutra, R. Dobbs, N. Pettit, A. Jankowski, T. Wallington, F. Kroon, D. Schmidt, B. Buttler, M. Stock, A. Veld, P. Speldewinde, B. A. Cook, B. Cook, M. Douglas, S. Setterfield, M. Kennard, P. Davies, J. Hughes, R. Cossart, N. Conolly, and S. Townsend. 2012. Assessment of the likely impacts of development and climate change on aquatic ecological assets in northern Australia. A report for the National Water Commission, Australia, Darwin, Northern Territory, Australia.

Comberti, C., T. F. Thornton, V. Wyllie de Echeverria, and T. Patterson. 2015. Ecosystem services or services to ecosystems? Valuing cultivation and reciprocal relationships between humans and ecosystems. Global Environmental Change 34:247-262. http:// dx.doi.org/10.1016/i.gloenvcha.2015.07.007

Crook, D. A., M. M. Douglas, A. J. King, and S. Schnierer. 2016. Towards deeper collaboration: stories of indigenous interests, aspirations, partnerships and leadership in aquatic research and management. Reviews in Fish Biology and Fisheries 26:611-615. http://dx.doi.org/10.1007/s11160-016-9449-7

Davis, A., and K. Ruddle. 2010. Constructing confidence: rational skepticism and systematic enquiry in local ecological knowledge research. Ecological Applications 20(3). http://dx.doi. org/10.1890/09-0422.1

Davis, A., and J. R. Wagner. 2003. Who knows? On the importance of identifying "experts" when researching local ecological knowledge. Human Ecology 31(3):463-489. http://dx.doi. org/10.1023/A:1025075923297

Dobbs, R. J., C. L. Davies, M. L. Walker, N. E. Pettit, B. J. Pusey, P. G. Close, Y. Akune, N. Walsham, B. Smith, A. Wiggan, P. Cox, D. P. Ward, F. Tingle, R. Kennett, M. V. Jackson, and P. M. Davies. 2016. Collaborative research partnerships inform monitoring and management of aquatic ecosystems by indigenous rangers. Reviews in Fish Biology and Fisheries 26(4):711-725. http://dx.doi. org/10.1007/s11160-015-9401-2

Dwyer, A. 2012. Pukarrikarta-jangka muwarr - stories about caring for Karajarri country. Australian Community Psychologist 24(1):11-23.

Elkin, A. P. 1933. Totemism in north-western Australia. Oceania 4(1):435-481. http://dx.doi.org/10.1002/j.1834-4461.1933.tb00087. $\underline{\mathrm{X}}$

Ens, E., M. L. Scott, Yugul Mangi Rangers, C. Moritz, and R. Pirzl. 2016. Putting indigenous conservation policy into practice delivers biodiversity and cultural benefits. Biodiversity and Conservation 25(14):2889-2906. http://dx.doi.org/10.1007/ $\underline{\text { s10531-016-1207-6 }}$

Ens, E. J., P. Cooke, R. Nadjamerrek, S. Namundja, V. Garlngarr, and D. Yibarbuk. 2010. Combining Aboriginal and nonAboriginal knowledge to assess and manage feral water buffalo impacts on perennial freshwater springs of the Aboriginal-owned Arnhem Plateau, Australia. Environmental Management 45 (4):751-758. http://dx.doi.org/10.1007/s00267-010-9452-Z

Ens, E. J., P. Pert, P. A. Clarke, M. Budden, L. Clubb, B. Doran, C. Douras, J. Gaikwad, B. Gott, S. Leonard, J. Locke, J. Packer,
G. Turpin, and S. Wason. 2015. Indigenous biocultural knowledge in ecosystem science and management: review and insight from Australia. Biological Conservation 181:133-149. http://dx.doi. org/10.1016/j.biocon.2014.11.008

Fox, C. A., N. J. Reo, D. A. Turner, J. Cook, F. Dituri, B. Fessell, J. Jenkins, A. Johnson, T. M. Rakena, C. Riley, A. Turner, J. Williams, and M. Wilson. 2017. "The river is us; the river is in our veins": re-defining river restoration in three indigenous communities. Sustainability Science 12(4):521-533. http://dx.doi. org/10.1007/s11625-016-0421-1

Gadgil, M., F. Berkes, and C. Folke. 1993. Indigenous knowledge for biodiversity conservation. Ambio 22(2/3):151-156.

Glaskin, K. 2007. Claim, culture and effect: property relations and the native title process. Pages 59-77 in B. R. Smith and F. Morphy, editors. The social effects of native title: recognition, translation, coexistence ANU E Press, Canberra, Australian Capital Territory, Australia.

Goodall, H. 2008. Riding the tide: indigenous knowledge, history and water in a changing Australia. Environment and History 14 (3):355-384. http://dx.doi.org/10.3197/096734008x333563

Gratani, M., J. R. A. Butler, F. Royee, P. Valentine, D. Burrows, W. I. Canendo, and A. S. Anderson. 2011. Is validation of indigenous ecological knowledge a disrespectful process? A case study of traditional fishing poisons and invasive fish management from the wet tropics, Australia. Ecology and Society 16(3):25. http://dx.doi.org/10.5751/es-04249-160325

Gratani, M., F. Royee, and J. R. A. Butler. 2016. A research process and criteria-indicators framework for developing indigenous freshwater ecosystem health monitoring. Cogent Environmental Science 2:1214228. http://dx.doi.org/10.1080/233$\underline{11843.2016 .1214228}$

Haggen, N., N. Turner, J. Carpenter, J. T. Jones, Q. Mackie, and C. Menzies. 2006. 12,000+ Years of change: linking traditional and modern ecosystem science in the Pacific Northwest. Fisheries Centre, University of British Columbia, Vancouver, British Columbia, Canada.

Hallwass, G., P. F. Lopes, A. A. Juras, and R. A. M. Silvano. 2013. Fishers' knowledge identifies environmental changes and fish abundance trends in impounded tropical rivers. Ecological Economics 23(2):392-407. http://dx.doi.org/10.1890/12-0429.1

Hankins, D. L. 2013. The effects of indigenous prescribed fire on riparian vegetation in central California. Ecological Processes 2 (1):24. http://dx.doi.org/10.1186/2192-1709-2-24

Hill, R., C. Grant, M. George, C. Robinson, S. Jackson, and N. Abel. 2012. A typology of indigenous engagement in Australian environmental management: implications for knowledge integration and social-ecological system sustainability. Ecology and Society 17(1):23. http://dx.doi.org/10.5751/es-04587-170123

Holmes, M. C. C., and W. (S. P.) Jampijinpa. 2013. Law for country: the structure of Warlpiri ecological knowledge and its application to natural resource management and ecosystem stewardship. Ecology and Society 18(3):19. http://dx.doi. org/10.5751/es-05537-180319 
Horstman, M., and G. Wightman. 2001. Karparti ecology: recognition of Aboriginal ecological knowledge and its application to management in north-western Australia. Ecological Management \& Restoration 2(2):99-109. http://dx.doi. org/10.1046/j.1442-8903.2001.00073.x

Howitt, R., and S. Stevens. 2010. Cross-cultural research: ethics, methods, and relationships. Pages 45-75 in I. Hay, editor. Qualitative research methods in human geography. Fourth edition. Oxford University Press, Oxford, UK.

Howitt, R., and S. Suchet-Pearson. 2006. Rethinking the building blocks: ontological pluralism and the idea of 'management.' Geografiska Annaler 88(3):323-335. http://dx.doi.org/10.1111/ j.1468-0459.2006.00225.x

Humphries, P. 2007. Historical indigenous use of aquatic resources in Australia's Murray-Darling Basin, and its implications for river management. Ecological Management \& Restoration 8(2):106-113. http://dx.doi.org/10.1111/ j.1442-8903.2007.00347.x

Huntington, H. P. 2005. "We dance around in a ring and suppose": academic engagement with traditional knowledge. Arctic Anthropology 42(1):29-32. http://dx.doi.org/10.1353/arc.2011.0101

Jackson, S., and P. O'Leary. 2006. Indigenous interests in tropical rivers: research \& management issues: a scoping study for Land \& Water Australia's Tropical Rivers Program. Prepared for the North Australian Indigenous Land and Sea Management Alliance (NAILSMA). CSIRO, Darwin, Northern Territory, Australia.

Jackson, S., M. Storrs, and J. Morrison. 2005. Recognition of Aboriginal rights, interests and values in river research and management: perspectives from northern Australia. Ecological Management \& Restoration 6(2):105-110. http://dx.doi. org/10.1111/j.1442-8903.2005.00226.X

Jackson, S. E., and M. Douglas. 2015. Indigenous engagement in tropical river research in Australia: the TRaCK program. Indigenous Policy Journal 6(2):1-23. http://dx.doi.org/10.18584/ iipj.2015.6.2.3

Jackson, S. E., M. M. Douglas, M. J. Kennard, B. J. Pusey, J. Huddleston, B. Harney, L. Liddy, M. Liddy, R. Liddy, L. Sullivan, B. Huddleston, M. Banderson, A. McMah, and Q. Allsop. 2014. "We like to listen to stories about fish": integrating indigenous ecological and scientific knowledge to inform environmental flow assessments. Ecology and Society 19(1):43. http://dx.doi. org/10.5751/ES-05874-190143

Jenkin, T., L. Ackland, and S. Muller. 2009. Towards a cooperative approach to the cultural and ecological assessment and management of rock-holes in the Gawler Ranges native title claim area. South Australian Arid Lands Natural Resources Management Board, Port Augusta, South Australia, Australia.

Kahui, V., and A. C. Richards. 2014. Lessons from resource management by indigenous Maori in New Zealand: governing the ecosystems as a commons. Ecological Economics 102:1-7. http://dx.doi.org/10.1016/j.ecolecon.2014.03.006

Kawharu, M. 2000. Kaitiakitanga: a Maori anthropological perspective of the Maori socio-environmental ethic of resource management. Journal of the Polynesian Society 109(4):349-370.
Kimberley Land Council (KLC). 2011. The KLC intellectual property and traditional knowledge policy. Kimberley Land Council, Broome, Western Australia, Australia. [online] URL: http://www.klc.org.au/news-media/research-facilitation

Kusabs, I. A., and J. M. Quinn. 2009. Use of a traditional Maori harvesting method, the tau kōura, for monitoring kōura (freshwater crayfish, Paranephrops planifions) in Lake Rotoiti, North Island, New Zealand. New Zealand Journal of Marine and Freshwater Research 43(3):713-722. http://dx.doi. org/10.1080/00288330909510036

Langton, M. 2006. Earth, wind, fire and water: the social and spiritual construction of water in Aboriginal societies. Pages 139-160 in B. David, B. Barker, and I. J. McNiven, editors. The social archaeology of Australian indigenous societies. Aboriginal Studies Press, Canberra, Australian Capital Territory, Australia.

Lansing, J. S. 2007. Priests and programmers: technologies of power in the engineered landscape of Bali. Princeton University Press, Princeton, New Jersey, USA.

Leonard, S., M. Parsons, K. Olawsky, and F. Kofod. 2013. The role of culture and traditional knowledge in climate change adaptation: insights from east Kimberley, Australia. Global Environmental Change 23(3):623-632. http://dx.doi.org/10.1016/ j.gloenvcha.2013.02.012

Liedloff, A. C., E. L. Woodward, G. A. Harrington, and S. Jackson. 2013. Integrating indigenous ecological and scientific hydro-geological knowledge using a Bayesian Network in the context of water resource development. Journal of Hydrology 499:177-187. http://dx.doi.org/10.1016/j.jhydrol.2013.06.051

Ligtermoet, E. 2016. Maintaining customary harvesting of freshwater resources: sustainable indigenous livelihoods in the floodplains of northern Australia. Reviews in Fish Biology and Fisheries 26(4):649-678. http://dx.doi.org/10.1007/s11160-016-9429-

\section{y}

Londono, S. C., C. Garzon, E. Brandt, S. Semken, and V. Makuritofe. 2016. Ethnogeology in Amazonia: surface-water systems in the Colombian Amazon, from perspectives of Uitoto traditional knowledge and mainstream hydrology. Pages 221-232 in G. R. Wessel and J. K. Greenberg, editors. Geoscience for the public good and global development: toward a sustainable future. Special Paper, Geological Society of America. Volume 520. Geological Society of America, Boulder, Colorado, USA. http:// dx.doi.org/10.1130/2016.2520(20)

Lourandos, H. 1980. Change or stability?: hydraulics, huntergatherers and population in temperate Australia. World Archaeology 11(3):245-264. http://dx.doi.org/10.1080/00438243.1980.9979765

Maclean, K., and E. Woodward. 2013. Photovoice evaluated: an appropriate visual methodology for Aboriginal water resource research. Geographical Research 51(1):94-105. http://dx.doi. org/10.1111/j.1745-5871.2012.00782.x

McGregor, S., V. Lawson, P. Christophersen, R. Kennett, J. Boyden, P. Bayliss, A. Liedloff, B. McKaige, and A. N. Andersen. 2010. Indigenous wetland burning: conserving natural and cultural resources in Australia's world heritage-listed Kakadu National Park. Human Ecology 38(6):721-729. http://dx.doi. org/10.1007/s10745-010-9362-y 
McGregor, W. B. 2003. Language shift among the Nyulnyul of Dampier Land. Acta Linguistica Hafniensia: International Journal of Linguistics 35(1):115-159. http://dx.doi. org/10.1080/03740463.2003.10416076

Millennium Ecosystem Assessment. 2005. Ecosystems and human well-being: current state and trends. Volume 1. Island Press, Washington, D.C., USA.

Moritz, C., E. J. Ens, S. Potter, and R. A. Catullo. 2013. The Australian monsoonal tropics: an opportunity to protect unique biodiversity and secure benefits for Aboriginal communities. Pacific Conservation Biology 19:343-355. http://dx.doi.org/10.1071/ $\underline{\mathrm{PC} 130343}$

Muller, S. 2012. 'Two ways': bringing indigenous and nonindigenous knowledges together. Pages 59-79 in J. K. Weir, editor. Country, native title and ecology. ANU E Press, Canberra, Australian Capital Territory, Australia. http://dx.doi.org/10.22459/ CNTE.03.2012.04

Neuendorf, K. A. 2002. The content analysis guidebook. Second edition. Sage, Thousand Oaks, California, USA.

Noble, M., P. Duncan, D. Perry, K. Prosper, D. Rose, S. Schnierer, G. Tipa, E. Williams, R. Woods, and J. Pittock. 2016. Culturally significant fisheries: keystones for management of freshwater social-ecological systems. Ecology and Society 21(2):22. http://dx. doi.org/10.5751/es-08353-210222

North Australian Indigenous Land and Sea Management Alliance (NAILSMA). 2014. Looking after country: the NAILSMA i-tracker story. NAILSMA, Darwin, Northern Territory, Australia.

Nursey-Bray, M., and Arabana Aboriginal Corporation. 2015. Cultural indicators, country and culture: the Arabana, change and water. Rangeland Journal 37(6):555-569.

Oades, D., and R. Meister. 2013. Bardi Jawi Indigenous Protected Area management plan 2013 - 2023. Kimberley Land Council/ Bardi Jawi Niimidiman Aboriginal Corporation RNTBC, Broome, Western Australia, Australia.

Paniagua-Zambrana, N., R. Cámara-Leret, R. W. Bussmann, and M. J. Macía. 2016. Understanding transmission of traditional knowledge across north-western South America: a cross-cultural study in palms (Arecaceae). Botanical Journal of the Linnean Society 182(2):480-504. http://dx.doi.org/10.1111/boj.12418

Pert, P. L., R. Hill, K. Maclean, A. Dale, P. Rist, J. Schmider, L. Talbot, and L. Tawake. 2015. Mapping cultural ecosystem services with rainforest Aboriginal peoples: integrating biocultural diversity, governance and social variation. Ecosystem Services 13:41-56. http://dx.doi.org/10.1016/j.ecoser.2014.10.012

Pettit, N. E., D. M. Warfe, P. G. Close, B. J. Pusey, R. Dobbs, C. Davies, D. Valdez, and P. M. Davies. 2016. Carbon sources for aquatic food webs of riverine and lacustrine tropical waterholes with variable groundwater influence. Marine and Freshwater Research 68(3):442-451. http://dx.doi.org/10.1071/MF15365

Preuss, K., and M. Dixon. 2012. 'Looking after country twoways': insights into indigenous community-based conservation from the Southern Tanami. Ecological Management \& Restoration 13(1):2-15. http://dx.doi.org/10.1111/j.1442-8903.2011.00631.
Pritchard, D., M. Ali, and T. Papayannis. 2016. Guidance: rapid cultural inventories for wetlands. Ramsar Culture Network, Ramsar Convention on Wetlands, Gland, Switzerland. [online] URL: http://www.ramsar.org/document/guidance-rapid-culturalinventories-for-wetlands

Pusey, B., editor. 2011. Aquatic biodiversity in northern Australia : patterns, threats and future. Charles Darwin University Press, Darwin, Northern Territory, Australia.

QSR. 2016. NVivo 11. QSR International Pty. Ltd, Doncaster, Victoria, Australia.

Rea, N., and the Anmatyerr Water Project Team. 2008. Provision for cultural values in water management: the Anmatyerr story. Research project number NTU18 of the Innovations Research Program of Land \& Water Australia. Land \& Water Australia, Canberra, Australian Capital Territory, Australia. [online] URL: http://lwa.gov.au/products/pr081464

Reyes-García, V., E. Kightley, I. Ruiz-Mallén, N. Fuentes-Peláez, K. Demps, T. Huanca, and M. R. Martínez-Rodríguez. 2010. Schooling and local environmental knowledge: do they complement or substitute each other? International Journal of Educational Development 30(3):305-313. http://dx.doi.org/10.1016/ j.ijedudev.2009.11.007

Reyes-García, V., J. Paneque-Gálvez, A. C. Luz, M. Gueze, M. Macía, M. Orta-Martínez, and J. Pino. 2014. Cultural change and traditional ecological knowledge: an empirical analysis from the Tsimane' in the Bolivian Amazon. Human Organization 73 (2):162-173. http://dx.doi.org/10.17730/humo.73.2.31n1363qgr30n017

Rogers, K. H., R. Luton, H. Biggs, R. Biggs, S. Blignaut, A. G. Choles, C. G. Palmer, and P. Tangwe. 2013. Fostering complexity thinking in action research for change in social-ecological systems. Ecology and Society 18(2):31. http://dx.doi.org/10.5751/ ES-05330-180231

Rose, D., D. Bell, and D. A. Crook. 2016. Restoring habitat and cultural practice in Australia's oldest and largest traditional aquaculture system. Reviews in Fish Biology and Fisheries 26 (3):589-600. http://dx.doi.org/10.1007/s11160-016-9426-1

Silvano, R. A. M., A. L. Silva, M. Ceroni, and A. Begossi. 2008. Contributions of ethnobiology to the conservation of tropical rivers and streams. Aquatic Conservation: Marine and Freshwater Ecosystems 18(3):241-260. http://dx.doi.org/10.1002/aqc.825

Singh, N. 2006. Indigenous water management systems: interpreting symbolic dimensions in common property resource regimes. Society and Natural Resources 19(4):357-366. http://dx. doi.org/10.1080/08941920500519297

Singh, R. K., O. Rallen, and E. Padung. 2013. Elderly Adi women of Arunachal Pradesh: "living encyclopedias" and cultural refugia in biodiversity conservation of the eastern Himalaya, India. Environmental Management 52(3):712-735. http://dx.doi. org/10.1007/s00267-013-0113-X

Smith, M. 1984. Bardi relationships with sea. Anthropological Forum 5(3):443-447. http://dx.doi.org/10.1080/00664677.1984.9967373

Strang, V. 1997. Uncommon ground: cultural landscapes and environmental values. Berg, Oxford, UK. 
Strang, V. 2009a. Integrating the social and natural sciences in environmental research: a discussion paper. Environment, Development and Sustainability 11(1):1-18. http://dx.doi. org/10.1007/s10668-007-9095-2

Strang, V. 2009b. Gardening the world: agency, identity, and the ownership of water. Berghahn Books, Oxford, UK.

Tengö, M., E. S. Brondizio, T. Elmqvist, P. Malmer, and M. Spierenburg. 2014. Connecting diverse knowledge systems for enhanced ecosystem governance: the multiple evidence base approach. Ambio 43(5):579-591. http://dx.doi.org/10.1007/ s13280-014-0501-3

Tengö, M., R. Hill, P. Malmer, C. M. Raymond, M. Spierenburg, F. Danielsen, T. Elmqvist, and C. Folke. 2017. Weaving knowledge systems in IPBES, CBD and beyond-lessons learned for sustainability. Current Opinion in Environmental Sustainability 26-27(Supplement C):17-25. http://dx.doi.org/10.1016/j. cosust.2016.12.005

Tipa, G., and K. Nelson. 2008. Introducing cultural opportunities: a framework for incorporating cultural perspectives in contemporary resource management. Journal of Environmental Policy \& Planning 10(4):313-337. http://dx.doi. org/10.1080/15239080802529472

Tipa, G., and L. Teirney. 2006. Using the cultural health index: how to assess the health of streams and waterways. Ministry for the Environment, Wellington, New Zealand.

Toussaint, S. 2014. Fishing for fish and for jaminyjarti in northern Aboriginal Australia. Oceania 84(1):38-51. http://dx.doi. org/10.1002/ocea.5034

Toussaint, S., P. Sullivan, and S. Yu. 2005. Water ways in Aboriginal Australia: an interconnected analysis. Anthropological Forum 15(1):61-74. http://dx.doi.org/10.1080/0066467042000336715

Toussaint, S., P. Sullivan, S. Yu, and M. Mularty, Jr. 2001. Fitzroy Valley indigenous cultural values study (a preliminary assessment). Report for the Water and Rivers Commission. Centre for Anthropological Research, The University of Western Australia, Nedlands, Western Australia, Australia. [online] URL: https:// www.water.wa.gov.au/ data/assets/pdf file/0018/4842/46326.pdf

Tuhiwai Smith, L. 2012. Decolonizing methodologies: research and indigenous peoples. Second edition. Zed Books, London, UK.

Turner, N. J., M. B. Ignace, and R. Ignace. 2000. Traditional ecological knowledge and wisdom of Aboriginal peoples in British Columbia. Ecological Applications 10(5):1275-1287. http://dx.doi.org/10.1890/1051-0761(2000)010[1275:TEKAWO]2.0. CO;2

Verzijl, A., and S. G. Quispe. 2013. The system nobody sees: irrigated wetland management and alpaca herding in the Peruvian Andes. Mountain Research and Development 33(3):280-293. http:// dx.doi.org/10.1659/MRD-JOURNAL-D-12-00123.1

Walsh, F. J. 2008. To hunt and to hold: Martu Aboriginal people's uses and knowledge of their country, with implications for comanagement in Karlamilyi (Rudall River) National Park and the Great Sandy Desert, Western Australia. Dissertation. The University of Western Australia, Perth, Western Australia, Australia.
Walsh, F. J., P. V. Dobson, and J. C. Douglas. 2013. Anpernirrentye: a framework for enhanced application of indigenous ecological knowledge in natural resource management. Ecology and Society 18(3):18. http://dx.doi.org/10.5751/ES-05501-180318

Western Australian Planning Commission. 2015. Dampier Peninsula planning strategy final report. Western Australian Planning Commission, Perth, Western Australia, Australia.

White, M., L. Ackland, M. Starkey, G. Scholz, and T. Jenkin. 2011. Partnerships in protecting rockholes: 2009-10 cultural and ecological site assessments in the Gawler Ranges. South Australian Arid Lands Natural Resources Management Board, Port Augusta, South Australia, Australia.

Woodward, E., and P. Marrfurra McTaggart. 2015. Transforming cross-cultural water research through trust, participation and place. Geographical Research 54(2):129-142. http://dx.doi. org/10.1111/1745-5871.12136

Young, D. 2006. Water as country on the Pitjantjatjara Yankunytjatjara lands South Australia. Worldviews: Global Religions, Culture, and Ecology 10(2):239-258. http://dx.doi. org/10.1163/156853506777965839

Yu, S. 1999. Ngapa kunangkul: living water: report on the Aboriginal cultural values of groundwater in the La Grange subbasin. Prepared by The Centre for Anthropological Research, University of Western Australia, for The Water and Rivers Commission of Western Australia. Perth, Western Australia, Australia.

Yu, S. 2006. Cultural studies of the Fitzroy River, WA. Pages 135-144 in R. Hill, K. Golson, P. A. Lowe, M. K. Mann, S. Hayes, and J. E. Blackwood, editors. Kimberley appropriate economies roundtable forum proceedings. Convened 11-13 October 2005, Fitzroy Crossing, WA, by the Kimberley Land Council, Environs Kimberley and Australian Conservation Foundation. Australian Conservation Foundation, Cairns, Queensland, Australia. 
Appendix 1. Interview questions about a water place.

1. Please tell us your English name, your bush name and the name of this place.

2. What is the meaning of this place to you? / Why is it important?

3. What did you do here when you were young?

4. Has this place changed since you were young?

5. (If yes to Q. 4) Can you tell us what this place looked like before it changed?

a. Why do you think that change happened?

b. Can you remember when that happened?

c. Was it a good or bad change and why?

6. Were there any ways that the old people looked after this place in the past? Should any of these things be happening today?

7. Do you come here now? / What do you do here now?

8. Tell me about the water here; which direction does it flow and is it fresh or salty?

9. Are there any cultural stories or songs, or dreamtime stories, about this place that you would like to share with us?

10. What does the Country need here to stay healthy into the future? 
Appendix 2. Initial broad coding frame used to analyse qualitative data.

\begin{tabular}{|c|c|c|}
\hline Theme & Sub-theme & Explanation \\
\hline \multirow[t]{2}{*}{$\begin{array}{l}\text { Factual } \\
\text { knowledge }\end{array}$} & Ecological attributes & $\begin{array}{l}\text { Ecological characteristics of wetlands } \\
\text { discussed including water levels and flows, } \\
\text { plants, animals, food webs, indicators of } \\
\text { healthy/unhealthy Country, weather, climatic } \\
\text { events and landuse. }\end{array}$ \\
\hline & Environmental change & $\begin{array}{l}\text { Any environmental change and its causes } \\
\text { discussed, related to either the site or broader } \\
\text { landscape. }\end{array}$ \\
\hline \multirow[t]{4}{*}{$\begin{array}{l}\text { Management and } \\
\text { use }\end{array}$} & Management system & $\begin{array}{l}\text { Intentional practical actions to manage } \\
\text { wetlands or their resources. }\end{array}$ \\
\hline & Management concerns & $\begin{array}{l}\text { Perceived threats or negative forces that may } \\
\text { adversely affect wetlands. }\end{array}$ \\
\hline & $\begin{array}{l}\text { Management ideas or } \\
\text { preferences }\end{array}$ & $\begin{array}{l}\text { Ideas or preferences for wetlands and how } \\
\text { they should be maintained / managed into the } \\
\text { future. }\end{array}$ \\
\hline & Use & $\begin{array}{l}\text { Use of or value attributed to wetlands. } \\
\text { Includes direct use of resources in or around } \\
\text { wetlands, or direct use of water bodies. Also } \\
\text { includes aesthetic, sacred site, historic or } \\
\text { other values. }\end{array}$ \\
\hline $\begin{array}{l}\text { Beliefs/ } \\
\text { worldviews }\end{array}$ & & $\begin{array}{l}\text { Perspectives that influence human } \\
\text { interactions with the environment. }\end{array}$ \\
\hline $\begin{array}{l}\text { Learning process } \\
\text { (knowledge } \\
\text { generation and } \\
\text { sharing) }\end{array}$ & & $\begin{array}{l}\text { Ways that participants learn new information } \\
\text { about wetlands, for example from family } \\
\text { members, revealed in dreams, direct } \\
\text { interaction with the environment, through use } \\
\text { / practical activities, stories, instructions by } \\
\text { elders or others. }\end{array}$ \\
\hline
\end{tabular}

